\title{
Relation of 'Latar' Location and Building Orientation in the Traditional House in Kota Lama Kudus
}

\author{
Anisa $^{1}$, Finta Lissimia ${ }^{1}$ \\ ${ }^{1}$ Department of Architecture, Faculty of Engineering, Universitas Muhammadiyah Jakarta \\ anisa@ftumj.ac.id
}

\begin{abstract}
In traditional houses, the "latar" has an important role. The "latar" is not just an open space that can be physically used for shared activities. But the "latar" has a deeper meaning. A phenomenon is found in the traditional Kudus house that the buildings in the house face the "latar", and not face the road. In connection with this phenomenon, a study was conducted aimed at uncovering the connection and interpreting the location of the "latar" with the orientation of the traditional Kudus house. This research is a descriptive interpretative qualitative research. Field data collection is done through direct observation in the Kudus traditional house to record and describe the arrangement of the building, setting the layout, and orientation of the building and is equipped with interview data. The results of the recording and description are then analyzed and interpreted to find the relationships and meanings contained in these relations. The results of this study showed two conditions: first, there was a relation between "latar" location and building orientation; secondly, the "latar" does not only serve as the center of the building orientation, and the binding between the buildings in the traditional Kudus house. But in meaning, the "latar" is also two essential activities carried out by the people of the Kota Lama Kudus, namely Ji-gang, reciting, and trading..
\end{abstract}

(C) 2019 IJBESR. All rights reserved.

Keywords: Latar, Building Orientation, Traditional House, Relation

\section{Introduction}

Kota Lama Kudus is an embryo of the Kota Kudus that exists today. Kota Kudus is better known as a city of students with special food, namely Jenang and Soto Kudus. In addition to the culinary specialties of Kudus, there is a cultural wealth that can be preserved in the form of a traditional Kudus house. Kota Kudus is divided into two, namely Kudus Kulon and Kudus Wetan, separated by a river called Kaligelis. Kudus Kulon is the place where Kota Kudus was founded. Kudus Wetan is the center of the city today. Many historical buildings can be found in Kudus Kulon or the Kota Lama Kudus. These historic buildings include the Masjid - Menara - Makam, the
Kudus traditional house, the Kilungan house, and the Gedong house.

"Latar" is a Javanese word that is defined as a yard. In general, "latar" or yard in the context of traditional architecture has an important role. The "latar" is not limited to building complements. For traditional houses arranged in groups, the "latar" can function as a shared space that is used for customary purposes. For a traditional house with a single form, the "latar" is the place where traditional activities and rituals of human life take place.

The "latar" in a traditional house is not only functional but also contains a deeper meaning. This can be seen as one of them in the 
traditional house of Kudus, which always has a "latar" as a complete building. The traditional house of Kudus, which still exists today in Kota Lama Kudus, has various forms. There is a traditional Kudus house in the form of an open single, a closed-form in a single, and a row of traditional Kudus houses. Kudus traditional house with complete type has a "sisir" combo that is used as a place of business. Uniquely, in the arrangement of the Kudus traditional house, the "latar" is more concerned with orientation than the existing road around it.

Preliminary research related to the traditional house of Kudus, among others, has been published in the Journal of Nalars vol 17 No. 2 titled Architectural Karakteristik Arsitektur di Kota Lama Kudus, National Seminar on SEMNASTEK 2017 with the title Keterkaitan Aktivitas Ekonomi Dengan Tata Ruang Rumah Tradisional Kudus Di Kota Lama Kudus, Journal of NALARs 11.1 January 2012 with the title Kesinambungan dan Perubahan Spasial pada Rumah Tradisional Kudus, Journal of NALARs 4.1. January 2005 with the title Pengaruh Faktor Ekonomi pada Tata Ruang Rumah Tradisional Kudus [1] [2] [3] [4]

This study aims to see the relationship between the location of the "latar" with the orientation of the traditional Kudus house. After knowing the connection, then interpret the meaning behind the connection.

\section{Material and Methods}

This study uses a descriptive qualitative interpretive method. Data collection is done in two-three ways. First, primary data were collected through field observations to the Kudus traditional house. Second, primary data was also obtained through direct interviews. Interviews were conducted to complete physical data and explore non-physical data. Third, secondary data is obtained through literature studies in relevant literature and publications.

The research material focused on is the traditional house of Kudus which is in the kilungan. The selection of this case study is based on a preliminary study that the traditional house of Kudus within the majority of the kilns has a unique arrangement and completeness of the building that is different from the traditional house of the Kudus row or single.To achieve the research objectives, the research steps are carried out as follows:

1) recording and describing the composition of the building of the traditional Kudus house and its latar

2) recording and describing the location of the latar of the overall structure of the building

3) recording and describing the orientation of the building

4) relate the latar location and the orientation of the building in the traditional Kudus house

5) Interpreting relations to express meaning

The number of houses studied was 5 case studies, all of which were in the villages of Kauman and Langgardalem.

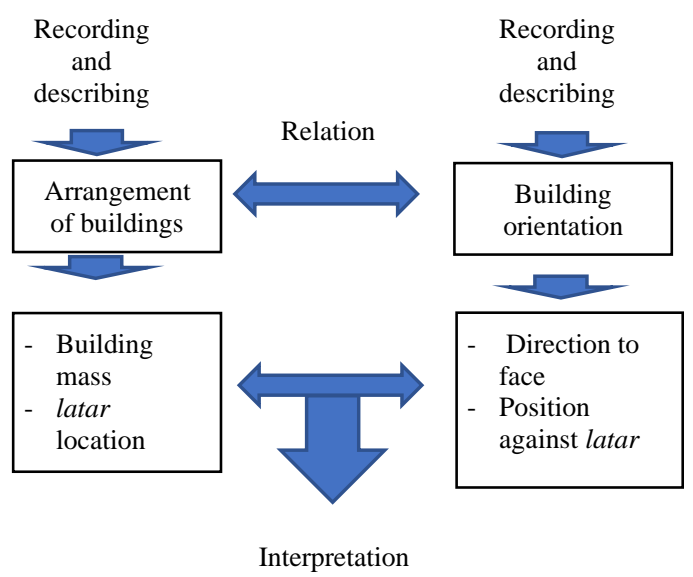

Figure 1: Research Framework 


\section{Results and Discussions}

\subsection{Theoretical Study: The Relationship between Function-Form-Meaning}

The theory used as a tool to discuss this research is the theory of the relation of functions - forms - meaning. This theory is used because in order to understand the relationship between the location of the latar and the orientation of the building, it must first be seen the function of the latar, the shape and arrangement of the latar, then to be associated with the orientation of the building and the construction of meaning interpretations.

Purnama Salura and Bachtiar Fauzy developed the concept of the function-form-meaning rotation. Every architectural design product must give priority to the elements of functionform-meaning. These three elements form a triangle shape, which is always in a state of change (spinning). This concept shows that architecture is always changing. (Figure 2). [5]

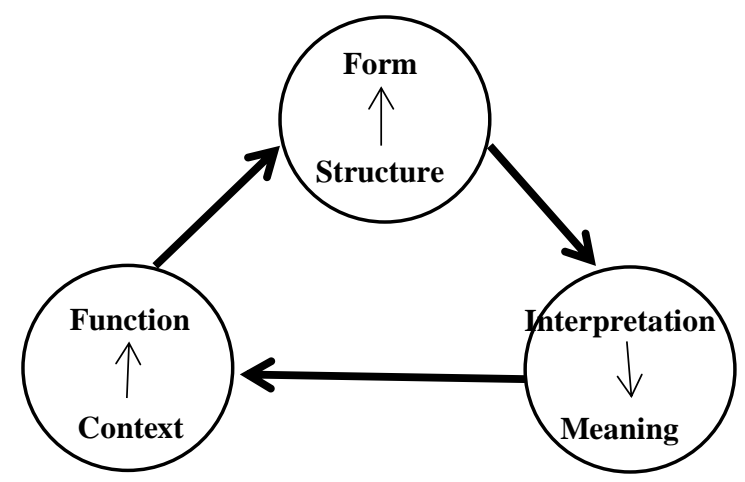

Figure 2: Concept Diagram of Relationship Aspects in Architecture according to Purnama Salura and Bachtiar Fauzy

\subsection{Kudus Traditional House}

Kudus traditional house is often called pencu house and carved house.

The uniqueness that was first seen is the roof shape of the joglo of Kudus traditional house which is higher and slightly pointed upwards.
Local people call it joglo pencu. The ornaments are placed on the ridge with shapes sticking out and look like fins. [6]

Kudus traditional house is not a single building but a unity of several buildings that serves as a place to live and carry out daily activities at home. The building layout pattern in the site consists of the main building, open courtyard and complementary buildings. The main building faces south, the position of the building on the north side of the site. Complementary buildings usually occupy positions south of the site opposite the main building and separated by an open courtyard in the middle of the site. [7]

There are several buildings within the scope of ownership of a traditional Kudus house. The building in question is the main building in the form of a traditional Kudus house, a sisir building as a place of business, and a bathroom building that is equipped with a well.The traditional house of Kudus in the Old City of Kudus, whether it is a lit house or not, usually has a yard within the scope of home ownership which is often referred to as internal viod, which is a tenuous area that is private ownership. [8]

Complementary buildings in the traditional Kudus house consist of a well and a bathroom and a sisir. This complementary building extends to cover the sides of the site outside the main building. Complementary buildings are used to accommodate service activities as well as economic or production activities of the occupants. sisir function for multipurpose room, or storage, comb function is largely determined by the work of the occupants. Sometimes the sisr is used for stalls on houses that are side by side with the road. The yard is an open space or courtyard in a traditional Kudus house. This page is an important part. Serves to bind the times of the buildings around it. [7] 
Kudus traditional house, also called pencu house based on the shape of the roof. Nazarudin's research on the Pencu House in Kudus found that there were several types of pencu houses in Kudus. This type of house gives a picture of the social existence of the Kudus community in the past [9]

The layout of the traditional houses in Kudus is proven to be very flexible. Pawon, sisir, and kolah can accommodate the needs of new spaces, making these parts of the house the first ones to be modified. The main house is the only part that seems to be sturdy with its shape, function, spatial arrangement plan, ornaments, and aesthetic. [10]

3.3. Recording and Describing Susunan Bangunan pada Rumah Tradisional Kudus dan Letak Latar

This research observes and describes five case studies of the Kudus traditional house. This section discusses the composition of the building of the traditional house of Kudus and the location of the latar in the traditional house of Kudus. The Kudus traditional house that was studied was the original and complete house, so that in one area of ownership there were several building masses.

Five cases showed the same pattern, all facing south, facing the courtyard and having a sisir building. Case study 1 is located in Kauman, a traditional-shaped house in Kudus with carved wooden gebyok and some buildings already using bricks. This house has an arrangement of jogosatru, gedongan and pawon. Pawon is on the right (west) and is used for daily cooking. The bathroom is in a separate part of the house, namely the front of the pawon.

In the south of the bathroom there is a building called a gotakan which is an elongated building consisting of only one room and used for large cooking. In this batch, it was used to cook glue while there was a cigarette factory,
Mustikaning Cigarettes. Gedongan in case study 1 still contains carvings that limit the spaces in sentong but the gedongan floor is no higher than jogosatru. Between gedongan and jogosatru there is a connecting door but it is rarely used. The way to reach Gedongan is by passing a large pawon. This connecting door is opened for example when there is a wedding ceremony. In this gedongan room, the bride sungkeman activities are carried out to the parents of the family.

Case Study 2 in the traditional form of Kudus facing south with the composition of jogosatru, gedongan and pawon in the east. Pawon room directly adjacent to the street / alley that is to the east. Pawons in this house are never used for cooking and are only used for children's play and leisure activities. Originally there was a carving of a gedongan but the floor on the gedongan had the same height as the jogosatru floor and some of the buildings were made of bricks. The gedongan room is now partitioned into 3 rooms and is still used for sleeping only the insulation in this room is not permanent.

Case study 3 in the traditional form of Kudus facing south with the layout of the jogosatru, gedongan and pawon rooms. Residential buildings are in the form of traditional Kudus houses, but there are only a few buildings that have brick materials. At the front of the pawon there are bathrooms, wells and gotakan.

At this gotakan place used for cooking from the past until now. In the pawon room, the activities carried out are casual activities and to receive guests. The actual living room is jogosatru and the room used for sleeping is a gedongan. In the gedongan there is still carving and division into 3 rooms. It's just that the floor on the gedongan is about $60-70 \mathrm{~cm}$ higher than the jogosatru floor. Right now the gedongan has the same height as jogosatru. At the front of the house there is a latar and a 
sisir building. This sisir building was used for chopping cloves and making tools from iron.

Case study 4 shaped traditional Kudus house facing south with one pawon. Pawon in this house is divided into two, big pawon and cooking pawon. The arrangement of space in this house is jogosatru, gedongan and pawon. It used to be taller than jogosatru and had a wooden floor. Right now, the gladagan and carved floors are gone. The space is now only used to store used goods. Big Pawon from the original is used as a place to relax and also as a place to sleep next to the building

Case Study 5 is the same as other traditional Kudus houses, namely jogosatru, gedongan, big pawon, sisir, bathroom and well and yard. From the first this house existed until now there has been no major change only there have been a few improvements to the sisir building. sisir building used to be for batik and for clove chopping place. The main building is in the form of a traditional Kudus and the gedongan room has a height of $60-70 \mathrm{~cm}$ above the jogosatru. Some of these houses are already made of bricks but for jogosatru and gedongan there are still many that come from carved wood.

\subsection{Recording and Describing Orientasi Bangunan pada Rumah tradisional Kudus}

In this section, the orientation of the building in the traditional Kudus house will be discussed, along with its position towards the latar. Direction facing all case studies to the south and facing the latar in front of it. The reason for making a house to the south has to do with the sun and the placement of rooms in the house. Previously in Kudus, most houses were in the traditional form of Kudus with rooms (sentong) located at the rear.

During the rainy season, the sun shines longer in the north so the rooms are placed in the north and the building faces south. because the bedroom is a private area it is placed farthest from the area that can be reached by many people. The bedroom is placed in the north so when the rainy season will get more sunlight and the room becomes warm. Then in summer, the sun will shine for a long time south and the sunlight coming into the room is not too hot because the room is located in the north. In essence, they try to keep entering the sun but adjusted to their needs and avoid blinding heat stings.

The case studies studied are all oriented towards the latar that is in front of the main building. The most important thing is the direction towards the main building while other buildings usually follow.

In case study 1, residential buildings, bathrooms, wells, booths and gotakan all face a latar that is in front of the residence and is in the middle of the land. So that the designation of the front direction of the building is the latar, so the whole building has an orientation towards the yard / latar. In this house, open space is only in the middle, which is in the form of a yard / latar which is the orientation of the buildings in the house

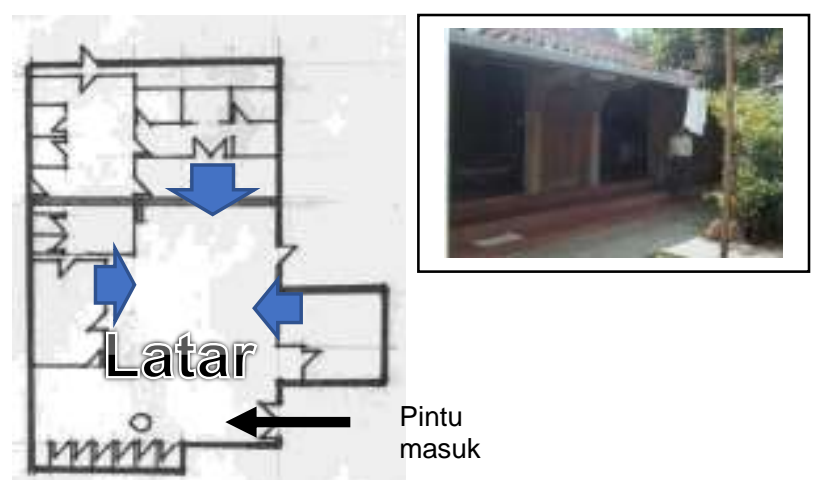

Figure 3: Latar location as the direction towards the building

Other buildings in the house such as houses, gotakan, bathrooms, wells are all at the ends and approach the walls of the house. Actually in the back of this house there is a hallway, the 
remaining space between this house and its neighbor's house, in some cases the hallway has a roof and floor so that it can be used for storing goods. This hallway is not referred to as open space.

Case study 3 The whole building has an orientation towards a latar. All buildings, starting from residential houses, gotakan and sisir, face the courtyard and this influences the direction. Houses on the north side, sisir and kebon buildings on the south side and gotakan, bathrooms and wells on the west side. Actually there is a fool in the southernmost side, but what is stated as open space is the background that is in front of the residence. Open space is between the residence of the sisir and the building.

In case study 4 all buildings face a background that exists between the house and the sisir building. Formerly the sisir building was used for batik and cigarette businesses, now the sisir building is used for storing unused items. The house is in the form of the Holy and facing the yard in front of it, as well as the bathroom, well and kitchen.

A similar explanation is found in case studies 2 and 5. This house consists of a main building, a sisir building, bathrooms and wells, latar and kebon. The residence is located in the north and faces south, in the background that is in front of his house. Building sisir facing north is facing the latar in front of its, as well as bathrooms and wells.

\subsection{Relation and interpretation}

The discussion in this section will relate the placement of the latar to the orientation of the building in the traditional Kudus house. In the previous section data recording has been discussed in 5 cases of Kudus traditional houses, which include the composition of the mass, the orientation of the building, the position of the building against the setting, and the location of the setting itself.

In the houses studied, the latar becomes an important and inseparable element in the traditional Kudus house. The latar is not only used as a direction facing the main building, the sisir building, the gotakan, the pawon, and the well. But more than that, the latar is an element of private open space that connects and ties between buildings in the traditional Kudus house.

Because the latar is in front of the main building, the mention is the latar ngarep. The original traditional Kudus house is always paired with a sisir building to support business activities. There is at least one sisir building that is paired with one house, but there is also a traditional Kudus house that has $2-3$ sisir buildings.

Until now, building orientation has become an important thing that has not changed. Although the sisir building around it has changed function. The original buildings owned are residential houses, sisir buildings, booths, bathrooms and wells and latar. Sometimes someone has a dough on the part adjacent to the sisir building. The kebonan is also an open space in the traditional Kudus house but does not become the direction of the building and is not called a setting.

As stated by Sardjono, that the yard is an open space and an important part that functions to bind the times of the buildings around it. [7]

\section{Conclusion}

This conclusion is used to answer the purpose of this study, which is to see the relationship between the location of the background with the orientation of the traditional Kudus house. After knowing the connection, then interpret the meaning behind the connection. 
Based on the recording and description which are then correlated and interpreted, the following conclusions can be obtained:

(1) This research was conducted in five complete type traditional Kudus houses, which have a main building (residential house) equipped with pawon, a sisir building, and a service area, namely bathrooms and wells. All traditional houses face south, with the latar in front of them, flanking the main building with a sisir.

(2) Although the Kudus traditional house has a different location to the road, it has the same building arrangement, the house in the south, the sisir in the north, and the latar in the middle.

(3) There is a strong relationship between the location of the latar and the orientation of the building in the traditional Kudus house. Physically the relation is seen in the latar which is used as the orientation of the building or direction to face the main building, the sisir building, pawon, and gotakan.

(4) In a meaning it can be explained that the latar is the binding of the building, not only the physical binding but also the binding of the activities carried out in the traditional Kudus house. As the Kota Lama Kudus said, the Kudus community has two main activities, namely jigang (ngaji-dagang). Both of these are done in the traditional Kudus house in a separate section by the yard. Mengaji activities are mostly done in the main building, and trading activities are carried out in the sisir building

\section{References}

[1] Anisa. (2016). Karakteristik Arsitektur Di Kota Lama Kudus. NALARs Jurnal Arsitektur Vol 17 No 2 Juli 2016.

[2] Anisa. (2017). Keterkaitan Aktivitas Ekonomi Dengan Tata Ruang Rumah Tradisional Kudus Di Kota Lama Kudus. Seminar Nasional Semnastek 2017.

[3] Anisa. (2012). Kesinambungan Dan Perubahan Spasial Pada Rumah Tradisional Kudus. NALARs Jurnal Arsitektur Vol 11 No 1 Januari 2012.

[4] Anisa. (2005). Pengaruh Faktor Ekonomi Pada Tata Ruang Rumah Tradisional Kudus. NALARs Jurnal Arsitektur Vol 4 No 1 Januari 2005.

[5] Ashadi, Anisa. (2019). Relation Of Architectural Function And Form Of Mosque Jami 'Al Mukarromah Kampung Bandan North Jakarta. International Journal Of Built Environment And Scientific Research Vol $3 \mathrm{No}$ 1 Juni 2019.

[6] Ashadi. (2010). Jejak Keberadaan Rumah Tradisional Kudus : Sebuah Kajian Antropologi Arsitektur Dan Sejarah. NALARs Jurnal Arsitektur Vol 9 No 2 Juli 2010

[7] Agung Budi Sardjono. Http://Eprints.Undip.Ac.Id/1769/1/Tata_Ruang_Rumah _Tradisional_Kudus_Full_Paper_.Pdf

[8] Anisa. (2008). Studi Awal Pola Ruang Kawasan Menara Kudus. NALARs Jurnal Arsitektur Vol 7 No 1 Januari 2008

[9] Nazaruddin, Imam. (2012). Rumah Pencu di Kudus : Kajian Berdasarkan Tipologi dan Pola Sebaran. Jurnal Berkala Arkeologi Vol 32 Edisi 1 Mei 2012

[10]. Suprapti, Atiek, Agung Budi Sardjono, Arnis Rochma, N.F Yasmina. (2014). The Tradition of Living of Muslim Community Kudus Kulon. Journal of Social Sciences Vol 10 No 2. ISSN 1549-3652. http://www.thescipub.com/jss.toc 
(This page is intentionally left blank) 